\title{
Land Administration Maintenance: A Review of the Persistent Problem and Emerging Fit-for-Purpose Solutions
}

\author{
Rohan Mark Bennett ${ }^{1,2, *}$, Eva-Maria Unger ${ }^{1}$, Christiaan Lemmen ${ }^{1,3}{ }^{-[}$and Paula Dijkstra ${ }^{1}$ \\ 1 Kadaster, The Netherlands Cadastre, Land Registry and Mapping Agency, \\ 7311 KZ Apeldoorn, The Netherlands; Eva-Maria.Unger@kadaster.nl (E.-M.U.); \\ Chrit.Lemmen@kadaster.nl (C.L.); Paula.Dijkstra@kadaster.nl (P.D.) \\ 2 Swinburne Business School, Swinburne University of Technology, Hawthorn, VIC 3122, Australia \\ 3 ITC Faculty, University of Twente, 7500 AE Enschede, The Netherlands; c.h.j.lemmen@utwente.nl \\ * Correspondence: rohanbennett@swin.edu.au
}

check for updates

Citation: Bennett, R.M.; Unger, E.-M.; Lemmen, C.; Dijkstra, P. Land Administration Maintenance: A Review of the Persistent Problem and Emerging Fit-for-Purpose Solutions. Land 2021, 10, 509. https://doi.org/ 10.3390/land10050509

Academic Editor: Volker Beckmann

Received: 1 April 2021

Accepted: 5 May 2021

Published: 11 May 2021

Publisher's Note: MDPI stays neutral with regard to jurisdictional claims in published maps and institutional affiliations.

Copyright: (c) 2021 by the authors. Licensee MDPI, Basel, Switzerland. This article is an open access article distributed under the terms and conditions of the Creative Commons Attribution (CC BY) license (https:// creativecommons.org/licenses/by/ $4.0 /)$.

\begin{abstract}
A contemporary review of land administration, from the perspective of systems maintenance, is provided. A special emphasis is placed on emerging fit-for-purpose land administration solutions. The research synthesis uses reputable sources from the contemporary era. Results show the challenges of maintaining land administration systems and the data held are long recognized. The 1970s-1980s gave the issue impetus as data and processes moved from paper-based and manual to digital and automated. The 1990s recognized concerns on maintenance, albeit as a secondary issue: system establishment was the primary concern. The 2000s placed more emphasis on more holistic sociotechnical systems but, again maintenance was supplementary. The fit-for-purpose era deliveres a vast range of new social and technological innovations; however, scaled and sustainable implementations still struggle with system maintenance. From the findings, a consolidated model for analyzing maintenance problems and solutions at jurisdictional level is developed. Maintenance of a land administration system can be understood by identifying the level of change, method for change, components to change, and options for what to change to. The United Nations-endorsed Framework for Effective Land Administration is then used to identify specific maintenance challenges and available solutions. It is suggested that due to the scope and size of what can be considered maintenance issues, there exists no single solution-instead the country should identify its persistant maintenance problems, and the most appropriate solution set from the suite of available options. Emerging solutions and challenges include ensuring interlinkage to maintenance of spatial planning, land valuation, and marine administration; exploiting survey data 'back capture' initiatives; supporting grassroots IT; and giving serious attention to cybersecurity concerns.
\end{abstract}

Keywords: maintenance; update; upgrade; upkeep; renewal; cadastre; land registration; data quality

\section{Introduction}

While much attention is afforded the establishment of land administration systems, less attention is given to ensuring they can be sustained and maintained [1]. That is, after an initial recording occurs of the parcel boundaries, associated rights, and the parties involved, processes for recording changes to those entities are ill-defined, poorly thought through, or inadequately resourced.

This creates many problems, not the least being that the significant upfront investment put into system establishment is wasted, and none of the intended longer-term benefits flow to the community [2].

The bias against maintenance has long been recognized in both the theory and practice of land administration [3], and the reasons for its occurrence are at least acknowledged anecdotally. Considerable effort has even been afforded to both conceptual and applied academic work on the issue $[4,5]$. 
The arrival of the fit-for-purpose land administration (hereafter FFPLA) philosophy supports the new wave of technical solutions [6]; ones that could also assist in dealing with the persistent problems of land administration maintenance. The elements of FFPLA are flexibility, inclusivity, participation, affordability, reliability, attainability, and perhaps most important to this work, upgradability. These can be achieved via establishment of appropriate legal, governance, and spatial frameworks. Despite the significant developments around FFPLA, evidence suggests that maintenance concerns are continuing to receive less attention in practice - even in more high-profile FFPLA projects [7]. Indeed, overwhelmingly, demonstrators, pilots, and implementations continue to focus on establishment procedures [8].

Therefore, emerging FFPLA approaches deserve appraisal, if not critique, in the context of land administration maintenance. Given the quantity and novelty of new approaches, there appears room for a comprehensive contemporary review of land administration maintenance solutions more generally.

To this end this paper undertakes a full review of available land administration literature, with a specific focus on maintenance and FFPLA developments. The aim is to reveal the state of play with regards to theoretical, methodological, and technological developments. The work acts as a reference and stepping off point for theoreticians and practitioners dealing with the various challenges associated with land administration maintenance, updates, upgrades, and other related terminology. Further, it invites these same actors to continue to explore more novel and emerging solutions to dealing with the maintenance issues.

Following this introductory section, an overview of the materials and methods underpinning the paper is provided. This is premised on a comprehensive review and synthesis of land administration literature. In terms of results, first the conventional challenges and solutions relating to land data maintenance are provided chronologically. Subsequently, the more recent fit-for-purpose approaches are introduced and evaluated. This leads to a synthesis of the entire domain of approaches, the relative merits and drawbacks, and persistent challenges and opportunities still requiring redress. The conclusion section provides an overarching summary and suggested areas for further work, both in practice and research.

\section{Materials and Methods}

The research activities underpinning this work can fundamentally be classified as research synthesis [9]. Research synthesis involves undertaking a form of systematic analysis of previous research outputs, with set constraints with regards to the scope of the body of literature, in terms of inclusion criteria, and reassembling the findings to create a novel contribution. Research synthesis is widely used across many domains, including the study area of land administration, with examples, inspiration, and justification for the approach in this particular work being found in [10-15].

The review involved a search bounded between January 1950 and December 2020. It was felt this rather expansive time period would surely include all identified challenges and opportunities relating to land administration maintenance in the contemporary era. In practical terms the majority of focus is post-1990: this is generally nominated as the starting point of increased global discourse on the widespread mainstreaming of cadastral and land registry data digitization and process digitalization. The digital computing approach was a paradigm shift for land administration—offering newer and more rapid methods of data capture, processing and storage [16], but also challenges in terms of ensuring data maintenance.

This is not to suggest that data maintenance issues did not exist prior to 1990. On the contrary, by the early 1990s, many colonial-era systems in 'developing' contexts were in states of decay or disrepair on account of open conflicts or administrative vacuums created in the post-colonial era $[17,18]$. The issue of maintenance and update was therefore pertinent; however, the amount of literature on the topic is markedly less, only growing 
in the 1990s, thanks largely to the discourse spawned by the International Federation of Surveyors (FIG), and an increased focus on 'pracademic' publishing, more generally.

In terms of searchable repositories, initial use was made of Google Scholar followed by Scopus and Science Direct searches. Additionally, the OICRF (International Office of Cadastre and Land Records; https:/ / www.oicrf.org/search) website, the dedicated land administration repository maintained by the Dutch Cadastre, Land Registry and Mapping Agency (Kadaster) was also searched. Standard Google searches also supplemented the academic searches, incorporating gray literature considered relevant into the study. Primary search terms and combinations included 'maintenance', 'update', 'upkeep', 'upgrade', and 'renewal' linked to 'land administration', 'cadastre', 'land registry', and 'fit for purpose'. While the above repositories and search terms resulted in returns of thousands of results in total, a process of snowballing [19] was used to ascertain when the list of relevant papers and reports was comprehensive. This resulted in approximately one hundred works being included in the final synthesis compilation. The analysis of the literature was both undertaken and reported chronologically. In this regard a complete and contemporary overview of the discourse on land administration maintenance is presented. The results of this work are presented in Section 3.

A synthesis in terms of the state of play and related challenges and opportunities identified was subsequently undertaken (presented in Section 4). The results of this part of the review were compiled descriptively, additionally via the development of a conceptual model and synthesis table. More details on the construction of these are provided in the relevant section, but it is worth noting that internationally recognized frameworks were used to guide the analysis and presentation (i.e., the Framework for Effective Land Administration or FELA, as endorsed via the United Nations Committee of Experts on Global Geospatial Information Management or UNGGIM).

\section{Results}

The land administration maintenance problem is not new, neither in academic literature, nor practice. The review work undertaken here confirms this notion. In terms of presentation of results, for simplicity, the results from the review of pre fit-for-purpose literature (i.e., <2010s) are presented in chronological sequence, generally organized by decade. The review results from the fit-for-purpose era are presented subsequently.

Effort is made to outline key terminology as it emerged in the literature, although it is necessary to define several key constructs upfront. In this work, 'land administration' is taken to be those activities used to determine and/or record the land tenures, land values, land use, and land development relationships between people and land. This aligns with the prevailing discourse $[16,20,21]$. It is taken to incorporate the concepts of 'cadastre' and 'land registration'. A cadastre is typically understood as the 'where' component of land administration, identifying the location of the land being administered. Meanwhile, 'land registration' tends to consider the 'who' and 'how' components of land administration [3]. However, there is much overlap with regards to these definitions, mostly stemming from practical historical developments in various jurisdictions - and these are not considered important to the discussion here. Finally, 'fit-for-purpose' land administration is an approach to land administration system development premised on the pragmatism and evolutionary improvement [6]. Other key terminology includes 'maintenance', 'update', 'upkeep', 'upgrade', and 'renewal': definitions on these are provided within the subsequent analysis.

\subsection{The 1950 s to $1980 \mathrm{~s}$}

While the scope of the review was primarily beyond the year 1990, it is important to note that scholarship countenanced the issue prior to this arbitrarily set date. The identifiable mentions tend to be brief, or implicit, stemming from works examining colonial-era administration regimes, although not always. For example, Singh [22] examines the context of India (circa 1834-1900), outlining the imperative for maintenance of land records for the Patwari in the northwestern provinces for revenue generation. Meanwhile, Hanstad [23], 
albeit writing in the 1990s, quoting the much earlier seminal work of [24] (p. 683), provides a more obvious example:

"A careful study of the long and abundant history of registration of rights to land shows that the difficulties that have so frequently been encountered ... due to defects in, or handicaps to, the daily working of the service, not to any extraneous disturbing conditions, and certainly not to fraud" (emphasis added).

Other pre-1990s works that touch upon the issue of maintenance are those written in the context of emerging digital database technologies, enabling the multipurpose cadastre concept, and coordinated cadastres. For example, Williamson [25] reveals the central importance of digital data and databases to support cadastral maintenance in common law jurisdictions. Others [26-31] provide positive examples from other jurisdictions. Flemming [28] provides the most obvious example of recognition that continuous maintenance is a core aspect of any cadastral system, providing a four-phase maintenance model with regards to different scales of map and survey, ranging from control surveys, to base mapping, to property ownership, to other types of land information. Braasch [29] speaks of phases of cadastral development, from graphical, to numerical, to coordinated, to computational-a process of improvement that remains relevant in the contemporary era. Through these two later examples, one begins to see the importance of distinguishing between updating the system and/or the qualities inherent in the system (i.e., system development/upgrade), versus updates to the data held within the system (i.e., data updates). However, the majority of works from pre-1990s, while making clear mention of the need for ongoing maintenance, do not do so in a way suggesting the need to differentiate between processes of establishment and ongoing upkeep.

\subsection{0 to 1999}

In the 1990s, the opportunity for entry of countries into the European Union from the former Soviet Union, following the end of the Cold War, was a boon for global discourse on the combined areas of cadastre and land registration, ultimately resulting in the broad adoption of the term 'land administration'. The International Federation of Surveyors (FIG) was particularly active in these developments, helping to record and formalize much of the discourse in conference proceedings and meeting reports. The narrower technology focus on digital cadastral databases (DCDBs) from the 1970s and 1980s gave way to a broader discourse on systems, including sociotechnical processes, institutional arrangements, and capacity development. Further aiding the discourse was the mainstreaming of the internet, enabling much easier access to scholarship than previously, and the globalization (or standardization) of academic scholarship of the 1990s.

This period ultimately resulted in creation of many foundational documents and references of the discipline [20,32-35]. The issue of maintenance is included, although again often as a tag-on to statements on establishment. Dale and McLaughlin [20] did go further to provide a standalone chapter on the processes of managing land administration, although they tend to limit the focus to technical reform, system reengineering, and project management (i.e., upgrades as opposed to day-to-day management or updates).

The 1990s marked an era when land administration systems were being challenged to undergo modernization, or renewal [36], due to the opportunities of digitalization, developments in geospatial technologies (e.g., geographic information systems or GIS, and global navigation satellite systems or GNSS), and demands for a more customer-oriented focus. This created opportunities for improving maintenance processes [37]. On this, Lemmen and Van Osterom [38] provided an overview of the specific case for the Netherlands, while [39] provided other examples from common law counties. On the impact of GNSS, others $[40,41]$ outlined that the geodetic basis for modern cadastres were becoming more dynamic (due to always-on GNSS stations, later known as CORS (continuously operating reference stations)), and that by association, cadastral boundaries also needed to be understood as dynamic, even in the physical sense, even if legal agreements were not changing. These sorts of developments resulted in the need to distinguish the day-to-day 
maintenance of land administration data (i.e., land transactions), from the larger-scale maintenance or improvement of land administration infrastructure (i.e., GNSS control networks, DCDB development and quality improvement, land regulation reform, etc.). In general, 'update' was used to refer to the former and 'upgrade' to the latter, although the distinction was not used universally $[5,42]$.

\section{3. $2000-2009$}

Up until this point, the majority of the discourse on 'updating' or 'upgrading' had focused on developed contexts. These contexts had long-established land administration systems with the capacity and resources to keep the data in those systems up-to-date. It was therefore natural for most attention to be afforded to the more 'modern' business of system upgrade, transformation or renewal. In the early 2000s, there were many works in this regard (e.g., [43-47]), with attention focusing on large-scale cadastral database management [48], remodeling property transactions [49], e-land administration, the role of cadastres in SDIs, and early work on 3D cadastres.

Meanwhile, less attention had been afforded to so-called developing contexts with regards to maintenance. In these contexts, inadequate land rights recognition was understood, among other factors, to entrench social inequality, increase poverty levels, disadvantage women, enable various forms of land grabbing from vulnerable groups, degrade land and natural resources, and ultimately impede economic growth [6]. This is not to say these contexts were not the focus of significant land administration efforts previously (or literature for that matter). Indeed, these contexts had been the focus for significant loans for land administration system development from the World Bank, and other international donors, for decades. By the late 1990s and early 2000s, however, it was increasingly apparent that these interventions and projects were failing to deliver on the expected social and economic benefits, and were not often being sustained: simple transfers of approaches and technology from the West were not appropriate [50]. The reasons for these failures are many, varied, and are documented elsewhere-but the failure to put in place sustainable maintenance processes, after the completion of the donor project, and the importance of doing so, was certainly recognized [23].

During this period in the 2000s, therefore, more urgency can be observed in calls to better understand [1] and find solutions to the data maintenance issue in developing contexts (albeit usually alongside calls for establishment or renewal of the systems in the first place [51]). This included seeking better ways to conceptualize, describe, and understand maintenance processes [4,5,52-54], identifying generalized best practices [55], and incorporating criteria and indicators into land administration systems, specifically relating to maintenance [56,57]. In these works, longstanding land administration terminology was reassembled into frameworks for better understanding the temporal aspects relating to land administration. This included grouping and redefining spatial updates (i.e., land subdivision, readjustment, or consolidation), updates to rights (i.e., land transfer, inheritance), and the length of time that a land right, restriction, or responsibility may apply (i.e., one-off, ad-hoc, repeat, indefinite, 'sunset clause') —and differentiating these day-today activities from full system redevelopment. Rearticulation of the difference between systematic and sporadic [20] adjudication and demarcation was also provided: systematic referred to covering a whole jurisdiction in a methodical fashion, while sporadic referred to capturing the data as transactions occurred. These approaches and terminologies sought to bring more clarity to the maintenance issue, providing a basis upon which to build more sustainable land data updating mechanisms, although embedding the ideas from theory into practice, at scale, would be more challenging.

\subsection{Fit-for-Purpose Land Administration Era (2010s Onwards)}

The 2010s continued the trends from the previous decade, crystalizing technology innovations into international standards and tangible tools. Terminology relating to 'upgrade' 
and 'renewal' focused increasingly, if not almost exclusively, on tools to enable transition from 2D to 3D cadastres [58-63].

Another key tool development that could support both upgrade and updating issues was ISO 19152, the Land Administration Domain Model (LADM) endorsed in 2012, a generic data model standard for land administration. The model was developed, in part, with the problems of data updating and system upgrading as core drivers [64]. The model found application and profile development (or comparison against existing systems) in many contexts [65-68]. Accompanying LADM was the Social Tenure Domain Model (STDM), intended as a more generalized version of LADM, sympathetic to the needs of contexts with customary, communal, and other non-Western land tenure types [69]. The Land Administration Domain Model and STDM represented truly tangible tools, at least at a technical level, for dealing with the maintenance issue: a generic data model might not only reduce system development costs, it could persist beyond the life of the any technology architecture, could be extended and be adapted, and be transferable when future system upgrades occurred.

In the 2010s, and of primary interest to this review paper, the philosophy and associated framework of fit-for-purpose land administration (i.e., FFPLA), also appeared [70]. The ideals behind the concept had long been understood, and can be said to have essentially grown out of pragmatic thinking (i.e., that associated with engineering disciplines), systems quality management (i.e., out of management disciplines), and evolutionary understandings of development. These philosophies now found more recognition in the land sector from the likes of FIG, the World Bank, and the Global Land Tool Network (GLTN). This saw the development of the 'continuum of land rights' metaphor, where the basic notion of land tenure was extended beyond conventional private and public typologies to include customary and communal forms of land holding, among others. In turn, as a technical response, the idea of FFPLA was that any land administration system must be designed and implemented taking into account the local circumstances and tenures, and should be open to improvement over time. Fit-for-purpose land administration consists of seven primary elements or desirable qualities, with one being upgradability [70]. That is, a system and its data should be constructed with a 'minimum viable' mindset in initial stages, but that over time the system itself and the data held within it could be improved or upgraded. Methods for delivering this upgradability were provided under three frameworks: institutional, legal, and spatial [71]. In this regard, the FFPLA approach and guidelines provided a tangible means by which to deal with the maintenance issue, starting from initial design, moving into day-to-day operations and system evaluation, and was applied as an analytical framework in numerous contexts [2,72-74]. However, like earlier land administration theories and methods, the emphasis tended to remain focused on establishment over maintenance.

The 2010s also saw the spawning of other land administration technology innovations that while not necessarily targeted at it, could further support responses to the maintenance challenge. Developments in high-resolution satellite imagery (HRSI) the decade before [75] started to find application in the land administration space [76-78], with novel methods combining data from older colonial cadastral maps with recent HRSI to develop upgraded digital cadastral fabrics [79]. Notwithstanding issues of cloud cover, the systematic repeated capture of images from the same location, at high resolution, again lent itself to being another data source to support maintenance.

Additionally, unmanned aerial vehicles (UAVs) or drones emerged as a lightweight and more flexible alternative to conventional aerial photography $[80,81]$. An issue with conventional photography was that over time, base imagery becomes outdated, and reflying areas is relatively costly. This is particularly an issue in urban or peri-urban areas where changes to land use and tenure can be quite rapid. With UAVs, imagery could be captured at a much lower price, with less expertise, and within a smaller desired areaalmost an ideal solution for the land administration data maintenance issue. As with other technology innovations, UAVs face regulatory blockers, issues with lack of trained capacity, 
and social concerns $[13,82]$; however, the solution is increasingly a standardized part of the land administration toolkit.

The proliferation of smartphones equipped with GNSS receivers and mapping capability also received much attention in the 2010s, also being mooted as a solution to data maintenance issues [83]. The democratization of mapping would enable citizen surveyors to map, record, and update their own land rights — sending them on to government- the so-called crowdsourced cadastre [84-87]. This idealized vision was somewhat stymied due to the trusted intermediary issue: it was not so much the mapping expertise that was essential for legalizing land rights, but more the need for a trusted agent of state to verify or reverify them. A mobile device could not do this on its own; nonetheless the seed was sown for a more democratized citizen-centric land administration system.

Blockchain or digital ledger technology (DLT) picked up on the democratization or libertarian trend, across multiple sectors, including land administration, and more specifically land registration. Conceptual works explored potential models of application in the sector, ranging from fully public permissionless chains, to more government-controlled private permission chains [88,89], the latter more closely replicating the existing technology and database systems of conventional land administration systems [14]. A range of experimentation and piloting work followed [90]. With regards to maintenance, blockchain solutions potentially distributed the responsibility and risks associated with maintaining land record information. In principle, this would seem a positive proposition; however, the approach could also significantly disrupt the business models of existing actors, including government land agencies, and as such, evidence of scaled application was limited by the close of the decade. It should also be noted that most of these discussions did not move past the demonstration or piloting phase, and typically issues of capacity and competencies needed to maintain and control a scaled system were not countenanced.

Towards the latter part of the 2010s, spurred on by developments in artificial intelligence (AI) and machine learning, the idea of automating updates (and even initial data capture) via automated feature extraction techniques gained substantial research and development (R\&D) focus [91-96]. Experimentation and piloting demonstrated the potential of the approach, including boundary change detection. Like other innovations, the conversion from R\&D 'cadastrobots' [97] to scaled implementation faces numerous institutional barriers, not to mention issues around quality, performance, and the costbenefit equation around needing to incorporate human actors into the process. The use of automated feature extraction techniques formed part of a broader examination of the visual nature of cadastral boundaries. While some boundaries are invisible to machine sensors, residing in agreement in the minds of people, many are not. In this regard, more attention was placed on increasing the emphasis on using natural or physical boundaries in cadastral updating - and thereby enabling automatic updating of those, via remote sensing technologies [98]. At the time of writing, these developments largely remain at the level of pilot or demonstration, not yet being considered robust enough to build production-level processes around.

Despite the technical innovations of the 2010s, and suggestions that processes for maintenance hardly differed from processes for the initial creation of data, and that therefore the same processes and tools could be applied [3], in practice the problems of ensuring effective and efficient land administration persisted, particularly in developing contexts. Even in countries where development and renewal programs had been considered a success, for example Rwanda and Turkey, the issue of keeping records up-to-date continued to demand research attention [7,99]. Indeed, the impetus was such that Zevenbergen et al. [2] even framed future research directions in the field entirely around better understanding five (5) levels of 'change': (i) changes in people-to-land relations; (ii) changes in technological possibilities; (iii) land use changes (due to urbanization); (iv) measuring changes; and (v) change agents. In this vein, there remains a strong argument to continue to explore potential options. 
Perhaps giving a boost to recognition on the need to better tend to the issues of maintenance, the UN-backed 2030 Agenda and accompanying Sustainable Development Goals (SDGs) provided emphasis on dealing with multiple land issues, particularly in developing contexts, and particularly with regards to securing and recognizing land rights. In this vein, the UNGGIM Expert Group on Land Administration and Management developed the FELA $[100,101]$, which openly sought to encapsulate maintenance approaches throughout:

"A reference for developing, reforming, renewing, strengthening, modernizing, and monitoring land administration." [102] (p. 1)

In addition, the nine Strategic Pathways making up the substantive or actionable parts of FELA generally all pay attention to aspects of maintenance. For example, in Strategic Pathway 4 on data:

"To support the creation and maintenance of land data, data custodianship, acquisition, management, supply chain, curation, metadata concerns, delivery strategies and mechanisms are needed. These should consider cross-sector and multidisciplinary issues-along with privacy and security concerns - and ultimately enable inclusive access and better ordering, integration and searching of information relating to property rights, restrictions, and responsibilities." (p. 23)

Additionally, for example, in relation to development and use of standards in Pathway 6 on standards:

"Standards also assist cost reduction and support removal of duplication and maintenance efforts." (p. 24)

Therefore, considering all the developments around FFPLA and FELA, perhaps at no earlier time has the emphasis on improving and ensuring day-to-day maintenance of land administration been given more attention: member state-endorsed UN documents make specific mentions and calls for action.

That said, it cannot be denied that implementing these ideals and technological innovations remains challenging in practice: it appears there exists no silver bullet or short term fix: a portfolio approach or suite of tools appears necessary. Therefore, having concluded reporting of the review results, this work makes an attempt to cluster or group the findings and cast forward to future developments.

\section{Synthesis and Discussion}

Having reviewed both pre- and post-FFPLA literature from the perspective of maintenance, this section seeks to take the synthesis further by (i) constructing a holistic overview of the terminologies, challenges, solutions, and relations with respect to maintenance; and (ii) presenting the maintenance solutions to those key concerns using a contemporary land administration framework: the Framework for Effective Land Administration (FELA) [100]. The aim here is not to conclusively 'solve' the issue land administration maintenance-the scope of that endeavor is outside a single academic paper, and at any rate as mentioned, there appear to be no silver bullets-rather, it is to provide a useful snapshot view of the key underlying problems, contemporary solutions, and areas still requiring further research endeavors.

\subsection{Consolidated Analytical Model of Land Administration Maintenance}

Figure 1 seeks to summarize the story of the maintenance concept in land administration - in terms of key terminology, typologies, approaches, aspects and optionsas it has developed over the previous decades, including the FFPLA era. It was constructed based on the results of the review and subsequent modeling/reasoning activities. For each of the parts of the diagram (i.e., rounded boxes) there are specific challenges to overcome when it comes to maintenance, and in many country contexts these issues remain unresolved. 


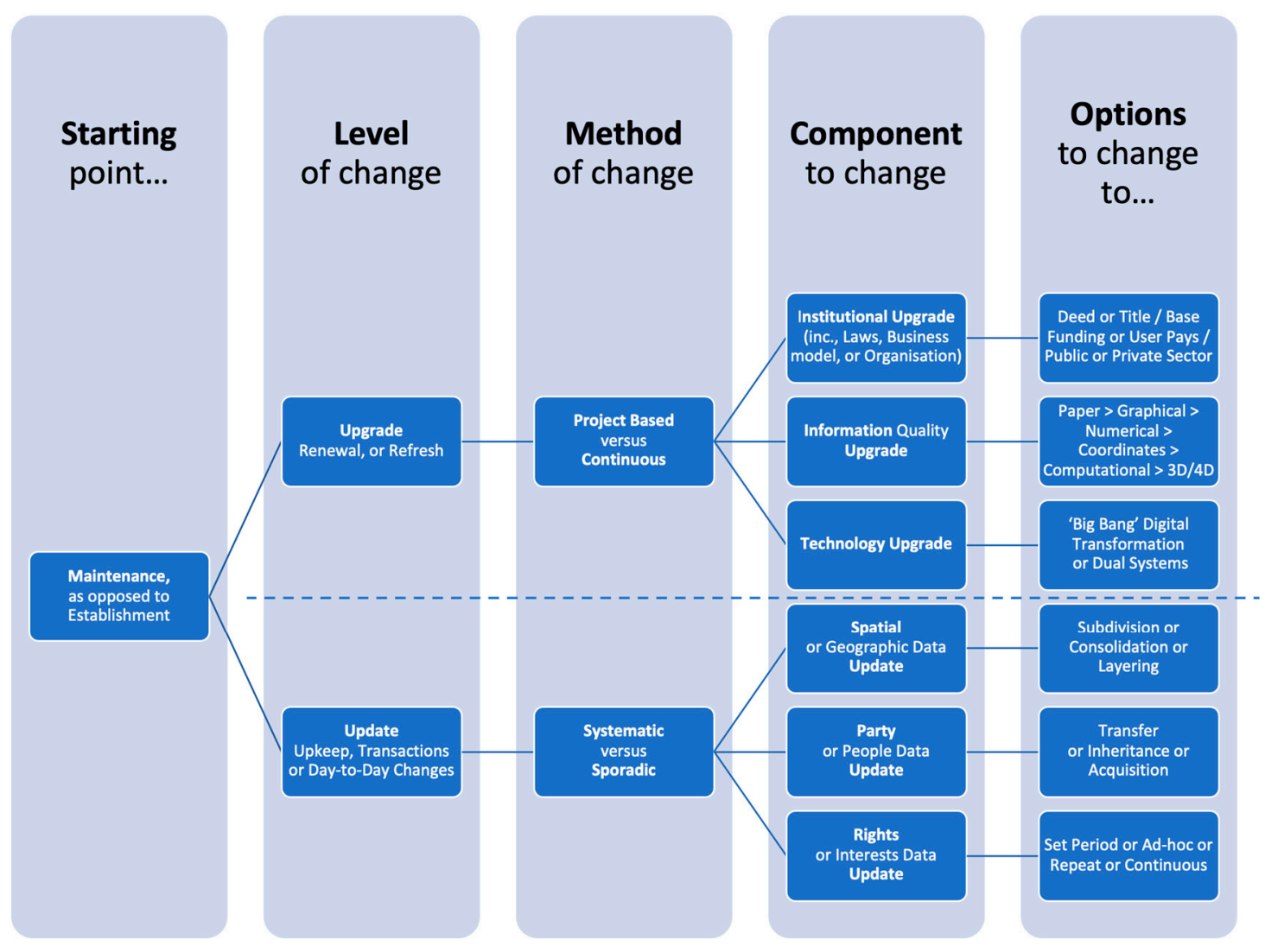

Figure 1. A model for analyzing maintenance in land administration.

Important to note is that the model only demonstrates ways of describing or understanding land administration maintenance; it does not provide judgement on most appropriate solutions to the challenges. The diagram is useful in that it helps to show the differentiation between terms in a crisp manner, as they are represented in the literature. Granted, some of the literature is less precise, but the key hierarchical breakdown is seen as useful for assisting theoreticians and practitioners in ensuring they are communicating on the same issue with the same terminology.

Unpacking the diagram further, first, it starts to become clear that, at least in terms of the existing literature, that beyond the breakdown of 'update' versus 'upgrade', there are essentially six central components that change: institutions, system quality, technology, spatial data, party data, and rights data. It should be noted that these could be possible grouped in any number of ways. For example, we could group the three types of data (i.e., spatial, part, right) into a single category. However, the six categories are decided upon as they are backed by the literature base. That is, each of these categories has a discrete body of research. At a minimum, the approach suggests that any jurisdiction or related land agency should have baseline knowledge, and preferably already enabled supportive processes, for ensuring appropriate maintenance of these components. This would already represent two indicators for measuring and monitoring maintenance within the jurisdiction.

Going further, the options for 'what to change to' or 'how to change' can also be systematically understood. In terms of institutions, this involves unpacking business models, subscription approaches, and even considerations of 'deeds' vs. 'title' approaches. For the component of system quality, this involves understanding where the jurisdiction is placed in terms of paper vs. graphical vs. numerical vs. coordinated vs. computational, and determining if and how to change, and whether leapfrogging between levels is necessary. For the technology architecture component, it involves making assessments as to whether parallel systems are needed and whether 'big bang' change implementations are most efficient or necessary. For the data components, it involves understanding and describing 
existing processes, assessing them for efficiency and effectiveness, from a range of stakeholder perspectives, and necessarily optimizing them. Of course, this process may have all kinds of change implications back at the previous levels: for institutional arrangements, system quality requirements and procedures, and/or technology architecture.

Whatever the case, the model (Figure 1) offers the ability to take a holistic perspective on maintenance, and to systematically work through existing approaches (and limitations), and potential strategies for improvements. Following on from Figure 1, in the next section, consideration is given to provide more depth and detail on the range of maintenance solutions by repacking the review results against the nine UNGGIM FELA Strategic Pathways. This not only supports providing a holistic view on solutions to maintenance, but also supports the operationalization of the relatively new FELA.

\subsection{Fit-for-Purpose Solutions for Land Administration Maintenance}

While Figure 1 provides a consolidated depiction of the key terms and issues surrounding land administration maintenance, from an historical point of view, as they have emerged in the literature, Table 1 takes more of a forward-looking perspective. It does this by utilizing the recently endorsed UNGGIM FELA, which is intended to support land administration renewal, reform, and monitoring alongside the UN SDGs, towards 2030. Table 1 provides a general overview of the major maintenance challenges, as identified in the literature, but now categorized by those nine FELA strategic pathways, alongside developed and emerging approaches, as also identified in the literature.

Table 1. Overview of land administration maintenance challenges, developed solutions, and the case examples from which those solutions are derived.

\begin{tabular}{|c|c|c|c|}
\hline $\begin{array}{c}\text { FELA } \\
\text { Strategic Pathway }\end{array}$ & Maintenance Problems & Available Solutions & $\begin{array}{c}\text { Specific } \\
\text { References and Recent Case } \\
\text { Examples }\end{array}$ \\
\hline $\begin{array}{l}\text { Governance and } \\
\text { Institutions }\end{array}$ & 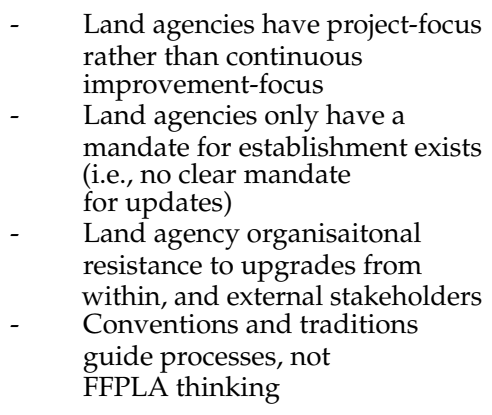 & 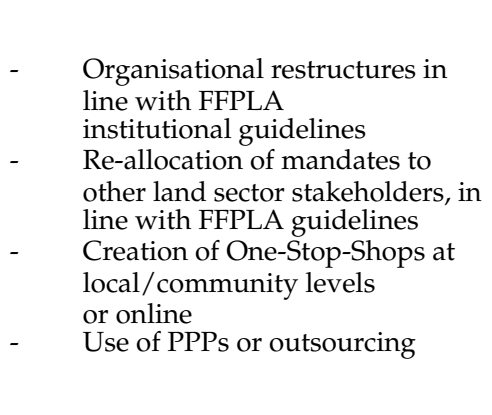 & $\begin{array}{l}{[12,16,20,50,56,69,74,84] ;} \\
\text { e.g., Rwanda; Namibia; Ethiopia; } \\
\text { Eastern European Countries; } \\
\text { Indonesia; Vietnam }\end{array}$ \\
\hline Law and Policy & $\begin{array}{ll}\text { - } & \text { No developed adopted policy on } \\
\text { updates or upgrades. } \\
\text { Failure to create laws for } \\
\text { updating and/or upgrading; } \\
\text { Regulations for data capture are } \\
\text { outdated or prescriptive } \\
\text { - Implementation and } \\
\text { enforcement of laws is not } \\
\text { in place }\end{array}$ & $\begin{array}{ll}\text { - } & \text { Whole-of-jurisidction FFPLA } \\
\text { policy development process } \\
\text { - } \quad \text { Specific legal reforms on } \\
\text { outdated or inadequate } \\
\text { legistration/regulations } \\
\text { De-regulation of maintenance } \\
\text { processes in terms of } \\
\text { requirements and } \\
\text { actosr involved } \\
\text { Prioritise moving towards digital } \\
\text { data over paper data, in } \\
\text { policy/law }\end{array}$ & $\begin{array}{l}{[3,4,13,17,23,32,43,55,98,100] ;} \\
\text { e.g., EU Inspire; Nepal; Colombia; } \\
\text { Rwanda; Mekong Delta Countries }\end{array}$ \\
\hline Finances & $\begin{array}{ll}\text { - } & \begin{array}{l}\text { Funding dependencies on } \\
\text { allocated government budget } \\
\text { (i.e., not self sustaining) }\end{array} \\
\text { - } \quad \text { Existing business models result } \\
\text { in government losses } \\
\text { - } \quad \text { Land agency rent } \\
\text { seeking behaviours } \\
\text { - } \quad \text { Petty and/or grand corruption }\end{array}$ & $\begin{array}{ll}\text { - } & \text { Free or subsidised registration } \\
\text { (subsidies) for } \\
\text { post-establishment land } \\
\text { transactions } \\
\text { More sustainable donor funding } \\
\text { models (less-project-oriented); } \\
\text { - } \quad \text { Pay-per-Use } \\
\text { - } \quad \text { Yearly fees or } \\
\text { subscripton models }\end{array}$ & $\begin{array}{l}\text { [20,36,49,51,56,57,74,81]; } \\
\text { e.g., Eastern European Countries; } \\
\text { Turkey; Indonesia }\end{array}$ \\
\hline
\end{tabular}


Table 1. Cont

\begin{tabular}{|c|c|c|c|c|}
\hline & $\begin{array}{l}\text { FELA } \\
\text { ategic Pathway }\end{array}$ & Maintenance Problems & Available Solutions & $\begin{array}{c}\text { Specific } \\
\text { References and Recent Case } \\
\text { Examples }\end{array}$ \\
\hline 4. & $\begin{array}{l}\text { Data and } \\
\text { Processes }\end{array}$ & $\begin{array}{ll}\text { - } & \text { Analogue data persists } \\
\text { - } & \text { across spatial and party data } \\
\text { - } & \text { Transactions remain paper } \\
\text { based/manual } \\
\text { - } \quad \text { New transactions are not } \\
\text { recorded } \\
\text { - } \quad \text { Spatial updates are not made } \\
\text { at all } \\
\text { Lack of quality of control over } \\
\text { data processes }\end{array}$ & 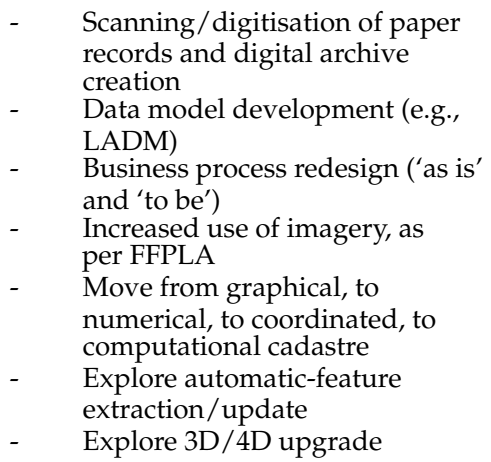 & $\begin{array}{l}{[7,14,17,18,48,51,56,67-72,93-103] ;} \\
\text { e.g., Pakistan, South Africa, } \\
\text { Nigeria, Malaysia, Indonesia, } \\
\text { Singapore, Australia/New } \\
\text { Zealand, Armenia, }\end{array}$ \\
\hline 5. & Innovation & $\begin{array}{l}\text { - } \\
\text { No innovation processes } \\
\text { embedded to promote and } \\
\text { enable change within } \\
\text { land agencies } \\
\text { - } \quad \text { No promotion of } \\
\text { entrepreneurship and/or } \\
\text { innovation in the land sector } \\
\text { No existing IT infrastructure } \\
\text { - } \quad \text { and/or technology blueprint; } \\
\text { Legacy IT infrastructure no } \\
\text { longer supported }\end{array}$ & $\begin{array}{ll}\text { - } & \text { Embed and promote innovation } \\
\text { processes into land agencies } \\
\text { - } \\
\text { Foster entrepreneurial acumen } \\
\text { amongst land sector } \\
\text { stakeholders, beyon } \\
\text { land agencies } \\
\text { Embed IT system renewal into } \\
\text { - } \quad \text { land administration processes } \\
\text { Replace or maintain parallel } \\
\text { IT system }\end{array}$ & $\begin{array}{l}\text { [2,14,51,59,62,73,82,84,87,88,90, } \\
\text { 103]; e.g., South Korea, Singapore, } \\
\text { Netherlands, New } \\
\text { Zealand/Australia, its4land } \\
\text { Project (Ethiopia, Rwanda, } \\
\text { Kenya), Slovenia, Dubai }\end{array}$ \\
\hline 6. & Standards & $\begin{array}{l}\text { - Lack of standards on initial } \\
\text { capture and maintenance } \\
\text { - Quality control and enforcement } \\
\text { issues, where standards do exist }\end{array}$ & $\begin{array}{l}\text { - } \quad \begin{array}{l}\text { Consdier utilization of ISO for } \\
\text { organisational management, } \\
\text { archive administration, and land } \\
\text { data model standards }\end{array} \\
\text { Consider also OGC on web } \\
\text { - } \\
\text { services standards } \\
\text { - } \quad \begin{array}{l}\text { Embed and mandate standards } \\
\text { uptake and adaptation processes } \\
\text { at national level }\end{array}\end{array}$ & $\begin{array}{l}\text { [13,49,52,56,57,64-69,100,101]; EU } \\
\text { Inspire; LADM/STDM pilots and } \\
\text { implementation; OGC web } \\
\text { service application examples }\end{array}$ \\
\hline 7. & Partnerships & 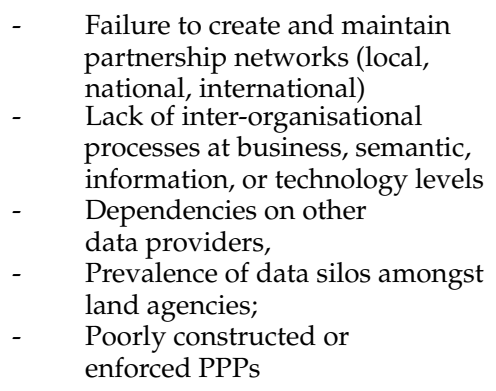 & $\begin{array}{ll}\text { - } & \text { Invest in partnership } \\
\text { building programs } \\
\text { - } \quad \text { Undertake inter-organisation } \\
\text { process mapping exercises with a } \\
\text { view to process redesign } \\
\text { Institute regular and more } \\
\text { meaningful land sector forums, } \\
\text { conferences and meetings, with } \\
\text { incentives (i.e., professional } \\
\text { development and accreditation) }\end{array}$ & $\begin{array}{l}{[8,15,17,18,50,55,83-87,90,100] ;} \\
\text { Eastern African Land } \\
\text { Administration Network } \\
\text { (EALAN); Network of Excellence } \\
\text { in Land Governance (NELGA); } \\
\text { Global Land Tool } \\
\text { Network (GLTN) }\end{array}$ \\
\hline 8. & $\begin{array}{l}\text { Capacity and } \\
\text { Education }\end{array}$ & $\begin{array}{l}\text { Staff skills outdated or beneath } \\
\text { required levels } \\
\text { - } \quad \text { Educaitonal curricula outdated } \\
\text { in terms of theories, methods, } \\
\text { and technologies } \\
\text { Staff composition too static or } \\
\text { too frequently changed } \\
\text { Cross-border or } \\
\text { cross-disciplinary brain-drain in } \\
\text { terms of IT/technical capacities }\end{array}$ & $\begin{array}{l}\text { - } \quad \text { Maintain staff skills and retrain } \\
\text { where necessary } \\
\text { - } \quad \text { Ensure staff renewal programs } \\
\text { and capacity creation programs } \\
\text { are instituted } \\
\text { Ensure close relationship } \\
\text { between ducational providers } \\
\text { and land agencies } \\
\text { Explore relevance and } \\
\text { appropriateness of out-sourcing } \\
\text { or off-shoring }\end{array}$ & $\begin{array}{l}\text { [16-18,21,52,55,82,97]; Rwanda, } \\
\text { Ethiopia, Namibia, Ghana, Kenya, } \\
\text { Uganda, Tanzania, South Africa, } \\
\text { Vietnam, Indonesia, Nepal, China, } \\
\text { South Korea }\end{array}$ \\
\hline 9. & $\begin{array}{l}\text { Communications } \\
\text { and Awareness }\end{array}$ & $\begin{array}{l}\text { Trust and awareness levels in } \\
\text { public are low } \\
\text { - } \quad \text { No engagement with processes } \\
\text { and public services } \\
\text { - No formalisedcommunication } \\
\text { plan or channels }\end{array}$ & $\begin{array}{l}\text { - } \\
\text { Establishment or refirm of PR } \\
\text { and media units within land } \\
\text { agencies } \\
\text { - } \\
\text { Regular and funded public } \\
\text { relations campaigns including } \\
\text { grass-roots programs } \\
\text { Establishment of local } \\
\text { one-stop-shops, where Internet } \\
\text { connectivity and remains limited }\end{array}$ & $\begin{array}{l}{[3,17,21,55,83,100] ; \text { Netherlands; }} \\
\text { Mozambique; Vietnam }\end{array}$ \\
\hline
\end{tabular}


As can be seen in Table 1, each of the nine pathways (column 1) is encumbered with challenges linked to maintenance (column 2), but in each case solutions are also available (column 3), with varying levels of maturity and application (column 4 ). In this regard, Table 1 acts as a consolidation of the broad suite of tools developed to combat the land administration maintenance challenge: while there may be no silver bullet, viewed holistically, the body of land administration literature focused on maintenance does already provide much guidance on what changes may be needed in land administration systems, and also how to make those changes.

For any jurisdiction grappling with land administration maintenance challenges, combined use of Figure 1 and Table 1 can help to assess the 'as is' situation in terms of performance or gaps in the existing system, and also to help chart the development of the 'to be' situation, via solution identification and selection from the range of developed and available approaches. For example, are issues primarily linked to law and policy, or data quality and standards, or communications and awareness, or a combination?

From the perspectives of the authors, and with numerous country experiences extending over at least four decades of professional practice, it is suggested that in many cases, it is the combination of unclear legal mandate, inadequate business models, and poor community communication and awareness, that often feeds into inadequacies around data quality and regular updating. Consequently, the solutions linked to those specific maintenance issues are perhaps of most utility and worthy of examination and potential application in many country contexts.

\subsection{Emerging Solutions and Issues}

In this final part of the discussion, focus is afforded several aspects, identified by the authors through the review process, as either (i) not identified in the literature review, but understood at least historically and/or anecdotally to be important in the context of land administration maintenance; and (ii) being innovations under development, but which are yet to appear in the academic literature.

First, the need to take a perspective beyond land administration processes alone appears important. Land administration establishment and maintenance does not exist in a vacuum: it interacts with many other government and community concerns. In this regard, it appears very necessary to ensure initiatives aimed at improving maintenance of land administration data are integrated, and interoperable with, related administrative areas such as spatial planning (including 3D), land valuation, and marine/coastal management. Already promising on this track are the developments taking place around the update of ISO 19152 LADM (i.e., LADM II).

Second, not covered in the review, but becoming increasingly apparent as a solution being employed in more developed contexts, is the concept of reconstructing cadastral fabrics based on original survey measurements, found on survey plans or field sketches (i.e., 'back capture' projects). This harks back to the evolutionary improvement process espoused in [29]. First-wave digital cadastral databases or layers, generally developed in the 1980s or early 1990s, made use of heads-up digitization of cadastral index maps, not the survey measurements themselves. This was generally seen as a faster and more appropriate way to develop digital cadastral layers. Technology limitations with regards to database size and the ability to effectively store large amounts of field computations also influenced the approach. Those original digital cadastral layers could only ever be of worse accuracy than the cadastral index maps they were digitized from, and in some cases, those were more topologically correct representations rather than anything approximating survey accuracy. For example, digitized boundary representations might be many meters displaced from actual locations on the ground, relative to other features. While there has been ongoing accuracy improvements, via rubber sheeting for example, as new data was brought into those cadastral layers over the decades, the maps are still generally considered as indexes to the original survey plans, rather than carrying any legal weight. Meanwhile, as database technologies and data exchange approaches have 
improved, and computer processing abilities have also, there now exists the possibility to go back to the original survey plans to rebuild or create from scratch a digital cadastral layer from the original survey measurements. Generally speaking, these measurements, while still containing errors, will be of far greater accuracy than the original index maps. These 'back capture' projects are now being actively explored and piloted in jurisdictions across Australia and the Netherlands, to name a few places. The processes suggested make use of a combination of manual and digital processes to capture data from those original plans, and even make use of artificial intelligence to identify and resolve errors (or disputes) within or between the original survey data. The approach, if successful, is likely to gain traction in other jurisdictions in the coming decade, as a way of leapfrogging cadastral layer quality upgrades, rather than the continuous improvement model from the previous decades.

Third, in the context of FFPLA, it needs to be noted that many of the emerging approaches, such as the 'back capture' approach mentioned above, or those listed in Table 1, even from the era of FFPLA (e.g., automatic feature extraction, blockchain), in reality remain quite distant from those countries or communities (i.e., developing contexts) in most need of sustainable approaches to maintenance. They are arguably too technology-intensive, demanding high levels of IT acumen, and large quantities of that expertise that simply does not exist in those jurisdictions. While many of those developments are driven and introduced with the idea that the innovations will eventually 'trickle down' to all stakeholders, which may or may not be realistic, it is worth considering how grassroots IT support can be provided and embedded into local communities. This would be in a similar vein to grassroots legal support and advice on land issues or the grassroots/barefoot surveyor concept. On this, the organization known as 'Namati' and the range of grassroots legal services they provide, acts as an example. This is not to say that such ICT4D (ICT for development) initiatives do not exist (c.f., [103]) with supportive methods under development, rather it is to say that in the context of a whole-of-jurisdiction land data infrastructure, providing more funding and support could be a way to ensure more sustainable maintenance of capture land data and transaction information.

Fourth, and finally, a gap in the land administration maintenance literature, especially around upgrades to digital data and processes, and solutions around outsourcing or use of cloud and webservices, appears to be that relating to cybersecurity and data privacy. The importance of securing land rights and transaction information has long been recognized [29], even in paper-based systems; however, cyber risks are increasingly recognized as a key business-continuity concern, not just IT concern, facing land agencies, and other government databases more generally. As mentioned, these issues could do with more attention in the land administration domain, particularly with regards to better understanding the sources and reasons of the threats, understanding whether existing or conventional approaches are satisfactory, and identifying and developing emerging cybersecurity and data privacy solutions that could be utilized in the land administration domain.

\section{Conclusions and Future Prospects}

This paper sought to provide a contemporary and consolidated update of the land administration maintenance challenge, both in terms of problems and solutions, and by including a particular emphasis on FFPLA, and what that has meant for maintenance more generally.

In this regard, a research synthesis was undertaken of land administration literature, using reputable databases and sources, from the 1950s to the contemporary era. The review identified that the challenges of maintaining land administration systems and the data held within them has been long recognized. The emergence of the digital era in the 1970s-1980s gave the issue more impetus as data and processes moved from paper-based and manual, towards digital and automated. The 1990s saw the more formal arrival of the domain of land administration; however, maintenance, while recognized, tended be a secondary concern as opposed to system establishment or complete rebuild, particularly 
as many post-Communist countries sought to establish cadastres. The 2000s placed more emphasis on more holistic, less technically-centric land administration designs, with sociotechnical systems thinking influencing developments, and with a special focus placed on building systems in developing contexts. Again, in general, maintenance was generally a secondary concern. The post-2010 FFPLA era has delivered a vast range of new social and technological innovations, and even countenanced the issue of maintenance, update, and upgrade more directly. However, while the underlying philosophy and supportive tools can be considered well formed, scaled implementations that are sustainable in terms of maintenance remain a challenge.

Following on, this paper consolidated those findings in terms of problems and solutions into a conceptual model, one enabling use at jurisdictional level, to unpack in more detail which specific aspects of maintenance may be problematic. This included breaking down the issue of maintenance into the level of change, methods for changing, components to change, and options for what to change to. Going further, it also utilized the recently endorsed UNGGIM FELA to explore more specific challenges to the nine strategic pathways in that framework, to illustrate the already available and emerging suite of solutions available to practitioners when it comes to resolving land administration maintenance issues, with a FFPLA mindset. It is suggested that due to the scope and size of what can be considered maintenance issues, there exist no silver bullets-instead a meaningful appraisal of Figure 1 and Table 1, for example, can help to identify the persistent maintenance problems within a country context, and the most appropriate solution set from the suite of available options. We encourage the use of and further reports on the approach outlined here, at a country level, and to have results of the application reported back to the academic community

Finally, while the review carried forward to the present era, it is also identified that new solutions, as yet unpublished, and newly identified challenges, are also emerging. These too could be the focus of further research effort, and relate to, for example, creating integrated maintenance processes of other spatial datasets, such as those relating to spatial planning, valuation, and the marine environment, transferring the lessons of the emerging 'back capture' cadastral projects in more developed jurisdictions, support for grassroots IT development (alongside grassroots lawyers and surveyors), and cybersecurity and data privacy concerns.

Author Contributions: Conceptualization, R.M.B. and C.L.; methodology, R.M.B.; validation, P.D., E.-M.U., and C.L.; formal analysis, R.M.B.; investigation, R.M.B.; data curation, R.M.B.; writingoriginal draft preparation, R.M.B.; writing-review and editing, E.-M.U. and P.D.; visualization, R.M.B. All authors have read and agreed to the published version of the manuscript.

Funding: This research received no external funding.

Institutional Review Board Statement: Not applicable.

Informed Consent Statement: Not applicable.

Data Availability Statement: Not applicable.

Acknowledgments: Many thanks to the School for Land Administration at the University of Twente, Netherlands for supporting the publishing of this study.

Conflicts of Interest: The authors declare no conflict of interest.

\section{References}

1. Van der Molen, P. The dynamic aspect of land administration: An often-forgotten component in system design. Comput. Environ. Urban Syst. 2002, 26, 361-381. [CrossRef]

2. Zevenbergen, J.; De Vries, W.; Bennett, R.M. Advances in Responsible Land Administration; Zevenbergen, J., De Vries, W., Bennett, R.M., Eds.; CRC Press: Boca Raton, FL, USA, 2015.

3. Henssen, J. Land Registration and Cadastre Systems: Principles and Related Issues; Technische Universität München: München, Germany, 2010. 
4. Zevenbergen, J. Systems of land registration aspects and effects. In Publications on Geodesy, 51; TU Delft: Delft, The Netherlands, 2002; Volume 51.

5. Effenberg, W. Spatial Cadastral Information Systems: The Maintenance of Digital Cadastral Maps. Ph.D. Dissertation, University of Melbourne, Melbourne, Australia, 2001.

6. Enemark, S.; McLaren, R.; Lemmen, C. Fit-for-Purpose Land Administration Guiding Principles; Global Land Tool Network (GLTN): Copenhagen, Denmark, 2015.

7. Biraro, M.; Bennett, R.; Lemmen, C. Accelerated land administration updates. In Advances in Responsible Land Administration; Zevenbergen, J., De Vries, W., Bennett, R.M., Eds.; CRC Press: Boca Raton, FL, USA, 2015; pp. 145-162.

8. Barry, M. Fit-for-purpose land administration-Administration that suits local circumstances or management bumper sticker? Surv. Rev. 2018, 50, 383-385. [CrossRef]

9. Rossiter, D.G. Research Concepts \& Skills Volume 1: Concepts; ITC Facuty, The University of Twente: Enschede, The Netherlands, 2011; p. 35.

10. Rockson, G.; Bennett, R.; Groenendijk, L. Land administration for food security: A research synthesis. Land Use Policy 2013, 32, 337-342. [CrossRef]

11. Simbizi, M.C.; Bennett, R.M.; Zevenbergen, J. Land tenure security: Revisiting and refining the concept for Sub-Saharan Africa's rural poor. Land Use Policy 2014, 36, 231-238. [CrossRef]

12. Alemie, B.K.; Bennett, R.M.; Zevenbergen, J. Evolving urban cadastres in Ethiopia: The impacts on urban land governance. Land Use Policy 2015, 42, 695-705. [CrossRef]

13. Stöcker, C.; Bennett, R.; Nex, F.; Gerke, M.; Zevenbergen, J. Review of the Current State of UAV Regulations. Remote Sens. 2017, 9, 459. [CrossRef]

14. Bennett, R.M.; Pickering, M.; Sargent, J. Transformations, transitions, or tall tales? A global review of the uptake and impact of NoSQL, blockchain, and big data analytics on the land administration sector. Land Use Policy 2019, 83, 435-448. [CrossRef]

15. Asiama, K.; Bennett, R.; Zevenbergen, J. Towards Responsible Consolidation of Customary Lands: A Research Synthesis. Land 2019, 8, 161. [CrossRef]

16. Williamson, I.; Enemark, S.; Wallace, J.; Rajabifard, A. Land Administration for Sustainable Development; ESRI Press Academic: Redlands, CA, USA, 2010.

17. Zevenbergen, J.; Augustinus, C.; Antonio, D.; Bennett, R. Pro-poor land administration: Principles for recording the land rights of the underrepresented. Land Use Policy 2013, 31, 595-604. [CrossRef]

18. Hendriks, B.; Zevenbergen, J.; Bennett, R.; Antonio, D. Pro-poor land administration: Towards practical, coordinated, and scalable recording systems for all. Land Use Policy 2019, 81, 21-38. [CrossRef]

19. Badampudi, D.; Wohlin, C.; Petersen, K. Experiences from using snowballing and database searches in systematic literature studies. In Proceedings of the 19th International Conference on Evaluation and Assessment in Software Engineering, Nanjing, China, 27 April 2015; pp. 1-10.

20. Dale, P.; McLaughlin, J. Land Administration; Oxford University Press: Oxford, UK, 2000.

21. Zevenbergen, J.; De Vries, W.; Bennett, R.M. Future directions in responsible land administration. In Advances in Responsible Land Administration; Zevenbergen, J., De Vries, W., Bennett, R.M., Eds.; CRC Press: Boca Raton, FL, USA, 2015.

22. Singh, A.K. The preparation and maintenance of the village land records-A case study of the office of the patwari in the north western provinces, 1834-1900. Proc. Indian Hist. Congr. 1987, 48, 491-501.

23. Hanstad, T. Designing land registration systems for developing countries. Am. U. Int'l L. Rev. 1997, $13,647$.

24. Dowson, E.; Sheppard, V.L. Land Registration; HM Stationary: London, UK, 1956.

25. Williamson, I.P. Cadastres and land information systems in common law jurisdictions. Surv. Rev. 1985, 28, 114-129. [CrossRef]

26. Dahlberg, R.E. The public land survey system: The American rural cadastre. Comput. Environ. Urban Syst. 1984, 9, 145-153. [CrossRef]

27. Kauter, B. The swiss cadastre and the district surveyor. Can. Surv. 1987, 41, 541-553. [CrossRef]

28. Flemming, N.L. Continuous updating-An essential requirement of a modern cadastre. Can. Surv. 1975, 29, 64-74. [CrossRef]

29. Braasch, H.W. The arrangement of numerical cadastral data in a modern cadastre of land holdings. Can. Surv. 1975, 29, 39-48. [CrossRef]

30. Williamson, I.P. The role of the Cadastre in a statewide land information system. Aust. Surv. 1983, 31, 567-581. [CrossRef]

31. Smith, G. Implementation of a co-ordinated Cadastre for South Australia. Aust. Surv. 1988, 34, 251-277. [CrossRef]

32. Kaufmann, J.; Steudler, D. Cadastre 2014: A Vision for a Future Cadastral System; FIG Commission 7: Berne, Switzerland, 1998.

33. International Federation of Surveyors. The FIG Statement on the Cadastre; International Federation of Surveyors: Canberra, Australia, 1995.

34. International Federation of Surveyors. Congress. The Bathurst Declaration on Land Administration for Sustainable Development; International Federation of Surveyors (FIG): Bathurst, Australia, 1999.

35. Larsson, G. Land Registration and Cadastral Systems; Tools for Land Information and Management; Longman Scientific and Technical: Harlow, Essex, UK, 1991.

36. Van Der Molen, P. Land registers and cadastre as prerequisites for land and building taxation: A case study of The Netherlands. In Proceedings of the XXVIII Incontro di Studio: Valori Immobilari Catasto e Fiscalita, Rome, Italy, 19 October 1998.

37. Polley, I.; Williamson, I. GIS, the Internet and the cadastre: Coming together. Aust. Surv. 1999, 44, 183-188. [CrossRef] 
38. Lemmen, C.; van Oosterom, P. Efficient and automatic production of periodic updates of cadastral maps. JEC 1995, 95, 137-142.

39. Dale, P.F.; McLaren, R.A. GIS in land administration. Geogr. Inf. Syst. 1999, 2, 859-875.

40. Grant, D.B. A dynamic datum for a dynamic cadastre. Aust. Surv. 1995, 40, 22-28. [CrossRef]

41. Blick, G.; Grant, D. Possibility of a dynamic cadastre for a dynamic nation. In Advances in Positioning and Reference Frames; Springer: Berlin/Heidelberg, Germany, 1998; pp. 107-113.

42. Effenberg, W.; Williamson, I.P. Digital cadastral databases: The Australian experience. In Proceedings of the AGI' 97 Conference, Birmingham, UK, 1997.

43. Enemark, S. Building land information policies. In Proceedings of the Special Forum on Building Land Information Policies in the Americas, Aguascalientes, Mexico, 26 October 2004; Volume 26, p. 2004.

44. Bogaerts, T.; Zevenbergen, J. Cadastral systems-alternatives. Comput. Environ. Urban Syst. 2001, 25, 325-337. [CrossRef]

45. Stoter, J.; Salzmann, M. Towards a 3D cadastre: Where do cadastral needs and technical possibilities meet? Comput. Environ. Urban Syst. 2003, 27, 395-410. [CrossRef]

46. Lauhkonen, H. Cadastral renewal in Finland-The challenges of implementing LIS. GIM Int. 2007, 21, 4.

47. Dawe, P.; Gariepy, D.; Hall, B. Integrated parcel maintenance: Trends and directions. Geomatica 2007, $61,410$.

48. Van Oosterom, P.J.; Lemmen, C.H. Spatial data management on a very large cadastral database. Comput. Environ. Urban Syst. 2001, 25, 509-528. [CrossRef]

49. Zevenbergen, J.; Frank, A.; Stubkjær, E. Real Property Transactions_Procedures, Transaction Costs and Models; IOS Press: Amsterdam, The Netherlands, 2007.

50. Fourie, C. Land management, land administration and geospatial data: Exploring the conceptual linkages in the developing world. Geomatica 2002, 56, 351-361.

51. Enemark, S.; Williamson, I.; Wallace, J. Building modern land administration systems in developed economies. J. Spat. Sci. 2005, 50, 51-68. [CrossRef]

52. Williamson, I.; Ting, L. Land administration and cadastral trends-A framework for re-engineering. Comput. Environ. Urban Syst. 2001, 25, 339-366. [CrossRef]

53. Bennett, R.; Wallace, J.; Williamson, I. Organising land information for sustainable land administration. Land Use Policy 2008, 25, 126-138. [CrossRef]

54. Navratil, G.; Frank, A.U. Processes in a cadastre. Comput. Environ. Urban Syst. 2004, 28, 471-486. [CrossRef]

55. Williamson, I.P. Land administration "best practice" providing the infrastructure for land policy implementation. Land Use Policy 2001, 18, 297-307. [CrossRef]

56. Burns, T.; Grant, C.; Nettle, K.; Brits, A.M.; Dalrymple, K. Land administration reform: Indicators of success and future challenges. Agric. Rural Dev. Discuss. Pap. 2007, 37, 1-227.

57. Steudler, D.; Rajabifard, A.; Williamson, I.P. Evaluation of land administration systems. Land Use Policy 2004, 21, 371-380. [CrossRef]

58. Vučić, N.; Roić, M.; Mađer, M.; Vranić, S.; Van Oosterom, P. Overview of the croatian land administration system and the possibilities for its upgrade to 3D by existing data. ISPRS Int. J. Geo-Inf. 2017, 6, 223. [CrossRef]

59. Drobež, P.; Fras, M.K.; Ferlan, M.; Lisec, A. Transition from 2D to 3D real property cadastre: The case of the Slovenian cadastre. Comput. Environ. Urban Syst. 2017, 62, 125-135. [CrossRef]

60. Guo, R.; Li, L.; Ying, S.; Luo, P.; He, B.; Jiang, R. Developing a 3D cadastre for the administration of urban land use: A case study of Shenzhen, China. Comput. Environ. Urban Syst. 2013, 40, 46-55. [CrossRef]

61. Vandysheva, N.; Sapelnikov, S.; Van Oosterom, P.J.; De Vries, M.E.; Spiering, B.; Wouters, R.; Hoogeveen, A.; Penkov, V. The 3D cadastre prototype and pilot in the Russian Federation. In Proceedings of the FIG Working Week 2012, Territory, Environment and Cultural Heritage, Rome, Italy, 6-10 May 2012.

62. Stoter, J.; Ploeger, H.; van Oosterom, P. 3D cadastre in The Netherlands: Developments and international applicability. Comput. Environ. Urban Syst. 2013, 40, 56-67. [CrossRef]

63. Oldfield, J.; Van Oosterom, P.; Beetz, J.; Krijnen, T.F. Working with open BIM standards to source legal spaces for a 3D cadastre. ISPRS Int. J. Geo-Inf. 2017, 6, 351. [CrossRef]

64. Lemmen, C.; Van Oosterom, P.; Bennett, R. The land administration domain model. Land Use Policy 2015, 49, 535-545. [CrossRef]

65. Elia, E.A.; Zevenbergen, J.A.; Lemmen, C.H.; Van Oosterom, P.J. The land administration domain model (LADM) as the reference model for the Cyprus land information system (CLIS). Surv. Rev. 2013, 45, 100-110.

66. Babalola, S.O.; Rahman, A.A.; Choon, L.T.; Van Oosterom, P.J.M. Possibilities of land administration domain model (ladm) implementation in Nigeria. ISPRS Ann. Photogramm. Remote Sens. Spat. Inf. Sci. 2015, II-2/W2, 155-163. [CrossRef]

67. Tjia, D.; Coetzee, S. Application of the land administration domain model to the city of johannesburg land information system. $S$. Afr. J. Geomat. 2013, 2, 260-279.

68. Zulkifli, N.A.; Rahman, A.A.; Van Oosterom, P.; Tan, L.C.; Jamil, H.; Teng, C.H.; Looi, K.S.; Chan, K.L. The importance of Malaysian land administration domain model country profile in land policy. Land Use Policy 2015, 49, 649-659. [CrossRef]

69. Antonio, D.; Zevenbergen, J.; Augustinus, C. Social tenure domain model: An emerging land governance tool. In Advances in Responsible Land Administration; CRC Press: Boca Raton, FL, USA, 2015; Volume 14, pp. 251-268.

70. Enemark, S.; Bell, K.C.; Lemmen, C.; McLaren, R. Fit-for-Purpose Land Administration; International Federation of Surveyors: Copenhagen, Denmark, 2014. 
71. Habitat, U.N. GLTN/Kadaster (2016) Fit-for-Purpose Land Administration: Guiding Principles for Country Implementation; E-book; United Nations Human Settlements Programme (UN-HABITAT): Nairobi, Kenya, 2016.

72. Musinguzi, M.; Enemark, S. A fit-for-purpose approach to land administration in Africa: Supporting the global agenda. Int. J. Technosci. Dev. 2019, 4, 69-89.

73. Moreri, K.; Fairbairn, D.; James, P. Issues in developing a fit for purpose system for incorporating VGI in land administration in Botswana. Land Use Policy 2018, 77, 402-411. [CrossRef]

74. Bennett, R.M.; Alemie, B.K. Fit-for-purpose land administration: Lessons from urban and rural Ethiopia. Surv. Rev. 2016, 48, 11-20. [CrossRef]

75. Alexandrov, A.; Hristova, T.; Ivanova, K.; Koeva, M.; Madzharova, T.; Petrova, V. Application of QuickBird satellite imagery for updating cadastral information. In Proceedings of the XX Congress of ISPRS, Istanbul, Turkey, 12-23 July $2004 ;$ pp. 386-391.

76. Ali, Z.; Tuladhar, A.; Zevenbergen, J. An integrated approach for updating cadastral maps in Pakistan using satellite remote sensing data. Int. J. Appl. Earth Obs. Geoinf. 2012, 18, 386-398. [CrossRef]

77. Bennett, R.; Oosterom, P.; Lemmen, C.; Koeva, M. Remote sensing for land administration. Remote Sens. 2020, 12, 2497. [CrossRef]

78. Rao, S.S.; Sharma, J.R.; Rajasekhar, S.S.; Rao, D.S.; Arepalli, A.; Arora, V.; Singh, R.P.; Kanaparthi, M. Assessing usefulness of high-resolution satellite imagery (HRSI) for re-survey of cadastral maps. In Proceedings of the ISPRS Annals of Photogrammetry, Remote Sensing \& Spatial Information Sciences, Hyderabad, India, 9-12 December 2014; Volume 2.

79. Sengupta, A.; Lemmen, C.; Devos, W.; Bandyopadhyay, D.; Van der Veen, A. Constructing a seamless digital cadastral database using colonial cadastral maps and VHR imagery-an Indian perspective. Surv. Rev. 2016, 48, 258-268. [CrossRef]

80. Puniach, E.; Bieda, A.; Ćwiąkała, P.; Kwartnik-Pruc, A.; Parzych, P. Use of unmanned aerial vehicles (UAVs) for updating farmland cadastral data in areas subject to landslides. ISPRS Int. J. Geo-Inf. 2018, 7, 331. [CrossRef]

81. Ramadhani, S.A.; Bennett, R.M.; Nex, F. Exploring UAV in Indonesian cadastral boundary data acquisition. Earth Sci. Inform. 2018, 11, 129-146. [CrossRef]

82. Koeva, M.; Stöcker, C.; Crommelinck, S.; Ho, S.; Chipofya, M.; Sahib, J.; Bennett, R.; Zevenbergen, J.; Vosselman, G.; Lemmen, C.; et al. Innovative remote sensing methodologies for kenyan land tenure mapping. Remote Sens. 2020, 12, 273. [CrossRef]

83. McLaren, R. Crowdsourcing support of land administration-A partnership approach. In Proceedings of the FIG Working Week 2012: Territory, Environment, and Cultural Heritage, Rome, Italy, 6-10 May 2012.

84. de Vries, W.T.; Bennett, R.M.; Zevenbergen, J.A. Neo-cadastres: Innovative solution for land users without state based land rights, or just reflections of institutional isomorphism? Surv. Rev. 2015, 47, 220-229.

85. Asiama, K.O.; Bennett, R.M.; Zevenbergen, J.A. Participatory Land Administration on Customary Lands: A Practical VGI Experiment in Nanton, Ghana. ISPRS Int. J. Geo-Inf. 2017, 6, 186.

86. Gkeli, M.; Potsiou, C.; Ioannidis, C. A technical solution for 3D crowdsourced cadastral surveys. Land Use Policy 2020, $98,104419$. [CrossRef]

87. Basiouka, S.; Potsiou, C. The volunteered geographic information in cadastre: Perspectives and citizens' motivations over potential participation in mapping. GeoJournal 2014, 79, 343-355.

88. Vos, J.A.; Lemmen, C.H.; Beentjes, B.E. Blockchain based land administration feasible, illusory or a panacea. In Netherlands Cadastre, Land Registry and Mapping Agency. Paper Prepared for Presentation at the 2017 World Bank Conference on Land and Povertry, Washington, DC, USA, 20-24 March 2017; The World Bank: Washington, DC, USA, 2017.

89. Lemieux, V.L. Evaluating the use of blockchain in land transactions: An archival science perspective. Eur. Prop. Law J. 2017, 6, 392-440. [CrossRef]

90. Bennett, R.; Miller, T.; Pickering, M.; Kara, A.-K. Hybrid approaches for smart contracts in land administration: Lessons from three blockchain proofs-of-concept. Land 2021, 10, 220. [CrossRef]

91. Wassie, Y.A.; Koeva, M.N.; Bennett, R.M.; Lemmen, C.H.J. A procedure for semi-automated cadastral boundary feature extraction from high-resolution satellite imagery. J. Spat. Sci. 2017, 63, 75-92. [CrossRef]

92. Crommelinck, S.; Bennett, R.; Gerke, M.; Nex, F.; Yang, M.Y.; Vosselman, G. Review of automatic feature extraction from high-resolution optical sensor data for UAV-based cadastral mapping. Remote Sens. 2016, 8, 689. [CrossRef]

93. Wierzbicki, D.; Matuk, O.; Bielecka, E. Polish cadastre modernization with remotely extracted buildings from high-resolution aerial orthoimagery and airborne LiDAR. Remote Sens. 2021, 13, 611. [CrossRef]

94. Xia, X.; Koeva, M.; Persello, C. Extracting cadastral boundaries from UAV images using fully convolutional networks. In Proceedings of the IGARSS 2019-2019 IEEE International Geoscience and Remote Sensing Symposium, Yokohama, Japan, 28 July-2 August 2019; pp. 2455-2458.

95. Kumar, P.; Rahman, A.A.; Buyuksalih, G. Automated extraction of buildings from aerial lidar point cloud and digital imaging datasets for 3D cadastre-preliminary results. In Cadastre: Geo-Information Innovations in Land Administration; Springer: Cham, Switzerland, 2017; pp. 159-165.

96. Luo, X.; Bennett, R.; Koeva, M.; Lemmen, C.; Quadros, N. Quantifying the overlap between cadastral and visual boundaries: A case study from vanuatu. Urban Sci. 2017, 1, 32. [CrossRef]

97. Bennett, R.; Asiama, K.; Zevenbergen, J. The intelligent cadastre. In Proceedings of the FIG Commission, St. Juliens, Malta, 16 November 2015; Volume 7.

98. Bennett, R.; Kitchingman, A.; Leach, J. On the nature and utility of natural boundaries for land and marine administration. Land Use Policy 2010, 27, 772-779. [CrossRef] 
99. Yildiz, O.; Erden, Ç. Cadastral updating: The case of Turkey. Surv. Rev. 2020, 7, 1-4. [CrossRef]

100. Unger, E.M.; Bennett, R.; Lemmen, C.; de Zeeuw, K.; Zevenbergen, J.; Teo, C.; Crompvoets, J. Global policy transfer for land administration and disaster risk management. Land Use Policy 2020, 99, 104834. [CrossRef]

101. de Zeeuw, K.; Benn, T.; Unger, E.M.; Bennett, R.; Teo, C. The proposed United Nations framework for effective land administration (FELA): Progress, pathways and prospects. In Proceedings of the Land and Poverty Conference 2020: Institutions for Equity and Resilience, Washington, DC, USA, 16-20 March 2020.

102. UNGGIM. Framework for Effective Land Administration, August 2021, New York, United States. Available online: https: //ggim.un.org/meetings/GGIM-committee/10th-Session/documents/E-C.20-2020-29-Add_2-Framework-for-EffectiveLand-Administration.pdf (accessed on 10 May 2021).

103. Kaur, R.; Ahamed, A.; Sargent, J.; Stockdale, R. Interactions in ICT4D projects: A sociotechnical perspective. In Proceedings of the 24th Pacific Asia Conference on Information Systems (PACIS 2020), Dubai, United Arab Emirates, 20-24 June 2020. 